Volume 5 Issue 2, September 2020:pp.164-179 Copyright @ LamLaj. Faculty of Law, Lambung Mangkurat University, Banjarmasin, South Kalimantan, Indonesia. ISSN: 2502-3136 | e-ISSN: 2502-3128. Open Access at: http://lamlaj.ulm.ac.id/web/

\title{
PENGGUNAAN ASURANSI TERHADAP RISIKO PELAKSANAAN JABATAN NOTARIS
}

\author{
Khairunnisa Noor Asufie ${ }^{1}$, Yulia Qamariyanti ${ }^{2}$, Rachmadi Usman ${ }^{3}$ \\ Mahasiswa Program Doktor Fakultas Hukum Universitas Brawijaya \\ Jl. MT. Haryono No.169, Ketawanggede, Malang, 65145, Indonesia \\ Email: annisaasufie@gmail.com
}

Fakultas Hukum Universitas Lambung Mangkurat Jl.Brigjen H.Hasan Basry Banjarmasin 70124, Indonesia

Email: yulia.qamariyanti@ulm.ac.id

Fakultas Hukum Universitas Lambung Mangkurat Jl.Brigjen H.Hasan Basry Banjarmasin 70124, Indonesia Email: usmanrachmadiu@gmail.com

Submitted:31/07/2020 Reviewed:23/09/2020 Accepted:30/09/2020

\begin{abstract}
Notary is public official appointed by the competent official in charge of private law sector. The Notary's authority is regulated in Article 15 of Act Number 2 of 2014 concerning Amendment to Act Number 30 of 2004 concerning Notary's Position. In his capacity as public official (openbaar ambtenaar) who is authorized to make authentic deeds, he is subject to liability. It is necessary to provide legal protection to the Notary's against the risk liability. Therefore, insurance for the Notary's position is deemeand necessary as an instrument of transfer of risk. The legal problem is that there is no insurance product for the Notary's liability and what kind of insurance it will be. The goals of this research are to study the urgency and form of the Notary's liability insurance. This normative legal research by studying the legal system, by using statute approach, conceptual approach, and comparative approach. The use insurance protection for Notary's position is considered urgent as one of the ways to transfer risk facing by the Notary and as form of legal protection for the Notary to be maximum in performing his duty. It can be a form of Professional Insurance and more specifically Notary Insurance which constitutes a general insurance in a form of new product made by insurance company to meet the necessity of the Notary in conducting his profession.
\end{abstract}

Keywords: Insurance; Risks; Notary's Position

Abstrak: Notaris merupakan pejabat umum yang diangkat oleh pejabat yang berwenang yang berperan dalam bidang hukum keperdataan. Kewenangan Notaris 
diatur dalam Pasal 15 Undang-Undang Nomor 2 Tahun 2014 Tentang Perubahan Undang-Undang Nomor 30 Tahun 2004 Tentang Undang-Undang Jabatan Notaris. Mengenai kewenangan Notaris sebagai pejabat umum (openbaar ambtenaar) yang berwenang membuat akta autentik dapat dibebani tanggung jawab atas akta autentik yang dibuatnya. Perlunya perlindungan hukum bagi Notaris terhadap risiko tersebut maka diperlukan adanya asuransi/pertanggungan jabatan Notaris sebagai salah satu cara pengalihan risiko. Permasalahan hukum yang terjadi adalah belum adanya produk asuransi/pertanggungan jabatan Notaris dan bentuk asuransi/pertanggungan jabatan Notaris. Tujuan dari penelitian ini untuk mengetahui urgensi dan bentuk dari asuransi/pertanggungan Jabatan Notaris. Penelitian hukum yang dilakukan merupakan penelitian hukum normatif dengan melakukan penelitian terhadap sistem hukum. Penelitian hukum yang dilakukan penulis dengan menggunakan pendekatan perundang-undangan, pendekatan konseptual, dan pendekatan perbandingan. Urgensi penggunaan perlindungan asuransi/pertanggungan jabatan Notaris merupakan suatu yang penting sebagai salah satu cara mengalihkan risiko yang dihadapi Notaris dan sebagai bentuk perlindungan hukum secara maksimal untuk Notaris dalam pelaksanaan jabatan. Penggunaan asuransi/pertanggungan terhadap risiko pelaksanaan Notaris dapat berupa Professional insurance lebih spesifik dalam bentuk Notary insurance yang merupakan bagian dari asuransi/ pertanggungan umum yang merupakan asuransi/pertanggungan kerugian dalam bentuk produk baru yang dibuat oleh perusahaan asuransi/pertanggungan sebagai pemenuhan kebutuhan asuransi/pertanggungan untuk Notaris dalam pelaksanaan jabatan Notaris.

Kata Kunci: Asuransi/pertanggungan; Risiko; Jabatan Notaris

\section{PENDAHULUAN}

Seseorang selama menjalani kehidupan maka tidak terlepas dengan adanya risiko yang harus dijalani. Risiko tersebut tidak dapat diketahui kapan waktunya datang dan besar atau kecilnya risiko tersebut. Risiko tidak lain adalah beban kerugian yang diakibatkan sesuatu diluar kesalahan. ${ }^{1}$ Salah satu cara yang saat ini banyak dipilih adalah dengan asuransi. Asuransi adalah sarana untuk mengalihkan risiko yang mungkin terjadi di kemudian hari.

Menurut ketentuan Pasal 246 Kitab Un-

\footnotetext{
${ }^{1}$ Angger Sigit Pramukti and Andre Budiman Panjaitan, Pokok-Pokok Hukum Asuransi. Cetakan I (Yogyakarta: Pustaka Yustia, 2016), 4.
}

dang-Undang Hukum Dagang: Asuransi/pertanggungan adalah suatu perjanjian, dengan mana, seorang penanggung mengikatkan diri kepada seorang tertanggung, dengan menerima premi, untuk memberikan penggantian kepadanya karena suatu kerugian, kerusakan atau kehilangan keuntungan yang diharapkan, yang mungkin akan dideritanya karena suatu peristiwa yang tak tentu. Selanjutnya Pasal 247 Kitab Undang-Undang Hukum Dagang (KUHD): Pertanggungan-pertanggungan itu antara lain dapat mengenai: bahaya kebakaran, bahaya yang mengancam hasil-hasil pertanian yang belum dipaneni, jiwa satu atau beberapa orang, bahaya laut dan pembudakan, bahaya yang mengancam pengangkutan 
di daratan, di sungai-sungai, dan di perairan darat. Mengenai dua macam pertanggungan yang tersebut terakhir. akan diatur didalam buku yang berikut.

Menurut ketentuan Pasal 1 angka (1) Undang-Undang Nomor 40 Tahun 2014 tentang Perasuransian: asuransi adalah perjanjian antara dua pihak, yaitu perusahaan asuransi dan pemegang polis, yang menjadi dasar penerimaan premi oleh perusahaan asuransi sebagai imbalan untuk memberikan penggantian kepada tertanggung atau pemegang polis karena kerugian, kerusakan, biaya yang timbul, kehilangan keuntungan, atau tanggung jawab hukum kepada pihak ketiga yang mungkin diderita tertanggung atau pemegang polis karena terjadinya suatu peristiwa yang tidak pasti atau memberikan pembayaran yang didasarkan meninggalnya tertanggung atau pembayaran yang didasarkan pada hidupnya tertanggung dengan manfaat besarnya telah ditetapkan dan/atau didasarkan pada hasil pengelolaan dana.

Notaris dalam menjalankan jabatannya sebagai seorang pejabat umum memiliki kewenangan yang termuat dalam Pasal 15 Undang-Undang Nomor 2 Tahun 2014 tentang Perubahan atas Undang-Undang Nomor 30 Tahun 2004 tentang Jabatan Notaris. Kewenangan Notaris, menurut Pasal 15 Undang-Undang Nomor 2 Tahun 2014 tentang Perubahan atas Undang-Undang Nomor 30 Tahun 2004 tentang Jabatan Notaris adalah membuat akta autentik mengenai perbuatan, perjanjian dan ketetapan yang diharuskan oleh peraturan perundang-undangan dan/atau yang dikehendaki oleh pihak yang berkepentingan untuk dinyatakan dalam akta autentik, menjamin kepastian tanggal pembuatan akta, menyimpan akta, memberikan grosse, salinan dan kutipan akta, semuanya itu sepanjang pembuatan akta-akta itu tidak juga ditugaskan atau dikecualikan kepada pejabat lain atau orang lain yang ditetapkan undang-undang. ${ }^{2}$

Seorang Notaris dalam menjalankan jabatannya memiliki kewenangan yaitu membuat akta autentik tapi karena kesalahan Notaris yang bersangkutan sehingga menyebabkan kekuatan pembuktian akta berubah menjadi akta dibawah tangan, maka para pihak dapat meminta ganti rugi kepada Notaris yang bersangkutan. Hal tersebut apabila seorang Notaris melanggar Pasal 41 Undang-Undang Nomor 2 Tahun 2014 yaitu tidak melaksanakan Pasal 38 Undang-Undang Nomor 2 Tahun 2014, Pasal 39 Undang-Undang Nomor 2 Tahun 2014, Pasal 44 ayat (5) Undang-Undang Nomor 2 Tahun 2014, Pasal 48 ayat (3) Undang-Undang Nomor 2 Tahun 2014, Pasal 49 ayat (4) Undang-Undang Nomor 2 Tahun 2014, Pasal 50 ayat (5) Undang-Undang Nomor 2 Tahun 2014, dan Pasal 51 ayat (4) Undang-Undang Nomor 2 Tahun 2014.

Apabila dalam pelaksanaan tugas serta kewenangannya seorang Notaris melakukan kesalahan atau pelanggaran maka seorang Notaris dapat dikenakan sanksi atas pelanggarannya tersebut. Atas pelanggarannya tersebut seorang Notaris dapat dikenakan sanksi terhadap pelanggaran Undang-Undang Jabatan Notaris dan Kode Etik Jabatan Notaris, kemudian dapat ditarik kedalam ranah hukum perdata, kesalahan seorang Notaris dalam ranah hukum perdata dapat dikenakan ganti rugi sebagai salah satu konsekuensi dari pelanggaran atau kesalahan yang dilakukan oleh seorang Notaris atas sebuah akta autentik yang telah dibuatnya. Seorang Notaris juga dapat ditarik menjadi pihak yang turut tergugat atas

\footnotetext{
2 Abdul Ghofur Anshori, Lembaga Kenotariatan Indonesia Perspektif Hukum dan Etika, Cetakan IV (Yogyakarta: UII Press Yogyakarta, 2016), 15.
} 
pelanggaran dan kesalahan dalam pembuatan akta yang dibuat oleh para pihak namun menimbulkan kerugian para pihak atau adanya pihak ketiga yang ikut dirugikan. Seorang Notaris juga tidak menutup kemungkinan dapat ditarik ke dalam ranah pidana karena jabatan Notaris yang dijalankannya, UndangUndang Jabatan Notaris dan Kode Etik Notaris tidak mengatur terkait tanggung jawab Notaris secara pidana terhadap akta yang dibuatnya manakala terbukti melakukan pelanggaran terhadap hukum pidana. Dalam Undang-Undang Jabatan Notaris hanya mengatur mengenai ketentuan sanksi-sanksi hukum perdata dan administrasi, Akan tetapi tanggung jawab Notaris secara pidana dikenakan apabila Notaris terbukti melakukan perbuatan pidana. ${ }^{3}$ Apabila terjadinya suatu pelanggaran pidana yang dilakukan oleh Notaris maka Notaris tersebut dapat dikenakan sanksi pidana berdasarkan pada Kitab Undang-Undang Hukum Pidana, adapun beberapa catatan bahwa pemidanaan tersebut dapat dikenakan terhadap Notaris dengan batasan yaitu :

1. Adanya tindakan hukum dari seorang notaris terhadap aspek lahiriah, formal dan materiil terhadap akta secara sengaja, penuh dengan kesadaran dan adanya niat yang direncanakan bahwa akta yang dibuat dihadapan Notaris secara saksama dengan para pihak dan penghadap sepakat dijadikan dasar untuk melakukan suatu

\footnotetext{
3 Irene Dwi Enggarwati, Suhariningsih, and Muchammad Ali Syafa'at, "Pertanggungjawaban Pidana dan Perlindungan Hukum Bagi Notaris yang Diperiksa oleh Penyidik Dalam Tindak Pidana Keterangan Palsu Pada Akta Otentik," Kumpulan Jurnal Mahasiswa Fakultas Hukum Universitas Brawijaya 5, no 1 (2015): 9, http://hukum. studentjournal.ub.ac.id/index.php/hukum/article/ view/1394
}

tindakan pidana; ${ }^{4}$

2. Ada tindakan hukum yang dilakukan oleh Notaris dalam pembuatan akta tersebut tidak sesuai dengan tata cara pembuatan akta berdasarkan pada Undang-Undang Jabatan Notaris; ${ }^{5}$

3. Adanya tindakan hukum tersebut tidak sesuai berdasarkan pada penilaian yang dilakukan oleh Majelis Kehormatan Notaris. Pemberian sanksi pidana terhadap Notaris dapat dilakukan manakala dalam melakukan jabatannya Notaris tersebut bertindak melanggar larangan-larang yang diatur dalam Undang-Undang Jabatan Notaris, Kode Etik Jabatan Notaris dan melanggar ketentuan dalam Kitab Undang-Undang Hukum Pidana ketiga unsur tersebut harus terpenuhi. ${ }^{6}$

Seorang Notaris dalam menjalankan jabatannya memiliki kewenangan untuk membuat akta autentik yang mana isi dari akta autentik tersebut merupakan keterangan dan kehendak para pihak dan apabila suatu waktu para pihak mengingkari isi dari akta autentik dan menyatakan isi dari akta autentik tersebut tidak seperti yang sebenarnya kemudian para pihak merasa dirugikan maka seorang Notaris dapat menjadi turut tergugat bahkan tergugat apabila para pihak mampu membuktikan bahwa ada unsur kesalahan yang disebabkan oleh seorang Notaris dalam menjalankan jabatannya misalnya memenuhi unsur perbuatan melawan hukum.

Seorang Notaris juga berpotensi dapat ditarik ke ranah pidana terkait dengan jabatan yang dijalankannya seperti Akta dibuat den-

\footnotetext{
4 Sjaifurrahman, Aspek Pertanggungjawaban Notaris dalam Pembuatan Akta, ed. Habib Adjie, (Bandung: Mandar Maju, 2011), 197.

5 Ibid.

${ }^{6}$ Ibid.
} 
gan kondisi para pihak tidak berhadapan, data identitas dari salah satu pihak dalam akta dianggap tidak benar atau dianggap memberikan keterangan palsu, data mengenai obyek yang diperjanjikan tidak sesuai dengan fakta yang sebenarnya, data yang diberikan oleh salah satu atau kedua pihak tidak benar, sehingga akta notaris yang diterbitkan dianggap akta palsu, ada dua akta yang beredar di para pihak, yang nomor dan tanggalnya sama tetapi isinya berbeda, tanda tangan salah satu pihak yang ada dalam minuta dipalsukan, dan penghadap menggunakan identitas orang lain. ${ }^{7}$

Berdasarkan penjelasan diatas maka seorang Notaris berpotensi dapat ditarik ke ranah perdata ataupun ranah perdata, dengan demikian maka dalam menjalankan jabatannya seorang Notaris dibayangi adanya risiko yang dapat menjeratnya kapan saja. Apabila seorang Notaris telah ditarik ke dalam ranah perdata ataupun perdata karena kesalahan yang dilakukan dalam jabatannya maka seorang Notaris biasanya memerlukan jasa pengacara atau lawyer untuk mendampinginya dalam proses tersebut, dan untuk hal tersebut biaya nya tidak sedikit. Kemudian Notaris yang melakukan kesalahan kemudian dikenai sanksi ganti rugi yang mengenai nominalnya besar atau kecil tidak dapat ditentukan, bisa saja dikenakan sanksi ganti rugi dengan nominal yang sangat besar sehingga dalam pemenuhan ganti rugi tersebut seorang Notaris mengalami kesulitan. Atas permasalahan ini maka asuransi/pertanggungjawaban Notaris diharapkan hadir sebagai suatu bentuk

\footnotetext{
7 Norman Edwin Elnizar, "Waspadai Tuntutan Pidana yang Mungkin Dihadapi Notaris dalam Bertugas," Hukum Online, last modified 2018 accessed August, 19 2020, https://www.hukumonline.com/berita/baca/ 1t5a 7ae033bc871/waspadai-tuntutan-pidana-yangmungkin-dihadapi-notaris-dalam-bertugas/
}

perlindungan untuk Notaris apabila terjadi hal yang demikian.

Beberapa negara maju para Notarisnya sudah menggunakan asuransi perlindungan dalam menjalankan jabatannya, seperti Texas, California, Amerika dan lain-lain. Jenis asuransi/pertanggungan juga beragam dan produknya juga beragam guna melindungi dari berbagai risiko yang salah satunya adalah ganti rugi.

\section{Rumusan Masalah}

Berdasarkan latar belakang yang telah diuraikan diatas, maka permasalahan yang dibahas adalah:

1. Bagaimana urgensi perlindungan asuransi/pertanggungan bagi Notaris terhadap risiko pelaksanaan jabatan Notaris?

2. Bagaimana bentuk asuransi/pertanggungan terhadap risiko pelaksanaan jabatan Notaris?

\section{METODE}

Penelitian tentang "Perlindungan Asuransi Terhadap Risiko Pelaksanaan Jabatan Notaris" merupakan suatu penelitian hukum normatif, penelitian hukum normatif atau kepustakaan mencakup penelitian terhadap asasasas hukum, penelitian terhadap sistematik hukum, penelitian terhadap taraf sinkronisasi vertikal dan horizontal, perbandingan hukum, an sejarah hukum. ${ }^{8}$ Penelitian normatif yang dilakukan dengan meneliti sistematika hukum asuransi/pertanggungan jabatan Notaris. Peneliti memilih tipe Reform Oriented Research yang berorientasi pada perubahan.

\footnotetext{
8 Soerjono Soekanto and Sri Mamudji, Penelitian Hukum Normatif Suatu Tinjauan Singkat, Cetakan XVIII. (Jakarta: PT. RajaGrafindo Persada, 2006 ), 22.
} 
Penelitian ini bersifat preskriptif analisis yaitu mempelajari tujuan hukum, nilai-nilai keadilan, validitas aturan hukum, konsepkonsep hukum dan norma-norma hukum. Penelitian ini dimaksudkan untuk memberikan argumentasi atas hasil penelitian sehingga menghasilkan pemikiran mengenai pengaturan penggunaan asuransi bagi Notaris terhadap risiko dalam pelaksanaan jabatannya yang mencerminkan asas keadilan dan kepastian hukum.

Dalam penelitian ini, Penulis menggunakan beberapa pendekatan, diantaranya:

1. Pendekatan peraturan perundang-undangan (Statue Approach), yaitu pendekatan yang dilakukan dengan menelaah semua undang-undang dan regulasi yang bersangkut paut dengan isu hukum yang sedang ditangani. ${ }^{9}$ Penelitian ini menelaah peraturan perundang-undangan terkait hukum asuransi dan hukum kenotariatan.

2. Pendekatan konseptual (Conceptual Approach), yaitu pendekatan yang dilakukan manakala peneliti tidak beranjak dari aturan hukum yang ada. Hal itu dilakukan karena memang belum atau tidak ada aturan hukum untuk masalah yang dihadapi. ${ }^{10}$ Penelitian yang beranjak dari pandangan-pandangan dan doktrin-doktrin yang berkembang dalam ilmu hukum. Pendekatan ini juga untuk menemukan gagasan dasar (basic ideas) dari konsep hukum, teori hukum dan asas-asas hukum yang relevan dengan isu hukum. ${ }^{11}$ Perlindungan asuransi/pertanggungan bagi Notaris terhadap risiko pelaksanaan jabatan Notaris

\footnotetext{
9 Peter Mahmud Marzuki, Penelitian Hukum Edisi Revisi (Jakarta: PT.Kharisma Putra Utama, 2005), 177

${ }^{10}$ Ibid.

${ }^{11}$ Ibid., 167.
}

merupakan suatu produk baru dalam perusahaan asuransi/pertanggungan di Indonesia, maka dari itu peneliti tertarik untuk mencari jawaban mengenai sistematika hukum penggunaan asuransi/pertanggungan jabatan Notaris. Pendekatan konseptual (Conceptual Approach) digunakan sebagai salah satu cara yang tepat untuk mendapatkan jawaban atas permasalahan tersebut.

3. Pendekatan perbandingan (Comparative Approach), yaitu studi perbandingan hukum merupakan kegiatan untuk membandingkan hukum suatu negara dengan hukum negara lain suatu waktu tertentu dengan hukum dari waktu yang lain, disamping itu juga membandingkan suatu putusan pengadilan yang satu dengan putusan pengadilan lainnya untuk masalah yang sama. Pendekatan perbandingan (Comparative Approach) dilakukan dengan melakukan perbandingan antara Notaris di Indonesia dan Notaris di luar negeri dalam menjalankan jabatannya yang telah mendapatkan perlindungan asuransi/pertanggungan dalam menjalankan jabatannya.

\section{ANALISIS DAN PEMBAHASAN}

Urgensi Penggunaan Asuransi/ Pertanggungan terhadap Risiko dalam pelaksanaan Jabatan Notaris

Asuransi/Pertanggungan Notaris di Beberapa Negara yang dapat Dijadikan Pedoman untuk Pemberlakuan Asuransi/ Pertanggungan Notaris di Indonesia

Asuransi berasal dari kata verzekering (Belanda) yang berarti pertanggungan. Istilah pertanggungan umumnya dipakai dalam literatur hukum dan kurikulum perguruan tinggi di Indonesia. Sedangkan isti- 
lah asuransi berasal dari istilah assurantie (Belanda) atau assurance (Inggris) lebih banyak dikenal dan digunakan oleh kalangan pelaku usaha (bisnis). Di Inggris, selain istilah assurance juga terhadap istilah pendampingnya, yaitu insurance. Bila istilah assurance cenderung digunakan untuk mengidentifikasi jenis asuransi jiwa, maka istilah insurance digunakan untuk jenis asuransi kerugian (umum). ${ }^{12}$

Asuransi atau dalam bahasa Belanda "verzekering" berarti pertanggungan. Dalam suatu asuransi terlibat dua pihak, yaitu yang satu sanggup menanggung atau menjamin, bahwa pihak lain akan mendapat pergantian suatu kerugian, yang mungkin akan diderita sebagai akibat dari suatu peristiwa yang semula belum tentu akan terjadi atau semula belum dapat ditentukan saat akan terjadi. ${ }^{13}$

Pengaturan mengenai asuransi/pertanggungan menurut Kitab Undang-Undang Hukum Dagang ada dua yaitu secara umum dan secara khusus. Pengaturan asuransi/pertanggungan secara umum terdapat dalam Buku I Bab 9 Pasal 246 sampai dengan Pasal 286 Kitab Undang-Undang Hukum Dagang. Pengaturan asuransi/pertanggungan secara khusus diatur dalam Buku I Bab 10 Pasal 287 sampai dengan Pasal 308 Kitab Undang-Undang Hukum Dagang dan dalam Buku II Bab 9 dan Bab 10 Pasal 592 sampai dengan Pasal 695 Kitab Undang-Undang Hukum Dagang.

\footnotetext{
${ }^{12}$ Aji Surya Pratama, Abdul Halim Barkatullah, and Rahmida Erliyani, "Kedudukan Dana Asuransi Jiwa Dalam Relevansinya Dengan Pembagian Harta Warisan," Lambung Mangkurat Law Journal 4, no. 1 (2019): 18, https://lamlaj.ulm.ac.id/web/index.php/ abc/article/view/93

${ }^{13}$ Wirjono Prodjodikoro, Hukum Asuransi di Indonesia (Jakarta: PT.Intermasa, 2007), 1.
}

Pengaturan asuransi/pertanggungan dalam Kitab Undang-Undang Hukum Dagang mengutamakan segi keperdataan yang didasarkan pada perjanjian Antara tertanggung dan penanggung. Perjanjian dalam asuransi/pertanggungan menimbulkan kewajiban dan hak yang saling bertimbal balik. Sebagai perjanjian khusus, asuransi/ pertanggungan dibuat secara tertulis dan disebut sebagai polis asuransi. Substansi pengaturan asuransi dalam Kitab UndangUndang Hukum Dagang meliputi: Asasasas asuransi, Perjanjian asuransi, Unsurunsur asuransi, Syarat-syarat (klausula) asuransi, Jenis-jenis asuransi. ${ }^{14}$

Definisi yang lebih luas daripada definisi dalam Pasal 246 Kitab UndangUndang Hukum Dagang adalah definisi asuransi dalam Pasal 41 New York Insurance Law. Dalam definisi tersebut menggunakan kata-kata to confer benefit of pecuniary value tidak digunakan to confer indemnity of pecuniary value. Pengertian benefit tidak hanya meliputi ganti kerugian terhadap harta kekayaan, tetapi juga meliputi pengertian "yang ada manfaatnya" bagi tertanggung.

Pengertian asuransi/pertanggungan diatur menurut ketentuan Pasal 1 angka (1) Undang-Undang Nomor 40 Tahun 2014 tentang Perasuransian yang mengatur lebih luas tentang asuransi/pertanggungan apabila dibandingkan dengan Pasal 246 Kitab Undang-Undang Hukum Dagang karena tidak hanya asuransi/pertanggungan kerugian juga memuat adanya asuransi/pertanggungan jiwa.

Berkembangnya zaman maka aturan hukum mengenai asuransi diperbaharui agar dapat selaras dengan perkembangan

\footnotetext{
${ }^{14}$ Ibid, 18 .
} 
zaman saat ini. Undang-Undang Nomor 40 Tahun 2014 tentang Usaha Perasuransian sebagai peraturan baru yang dibuat sebagai upaya untuk menciptakan perasuransian yang lebih sehat, dapat diandalkan, amanah, dan kompetitif secara umum dilakukan, baik dengan penetapan ketentuan baru maupun dengan penyempurnaan ketentuan yang telah ada. Pengaturan Undang-Undang Nomor 40 Tahun 2014 tentang Usaha Perasuransian dalam pengaturannya mencerminkan perhatian dan dukungan besar bagi upaya perlindungan konsumen jasa perasuransian, upaya antisipasi lingkungan perdagangan jasa yang lebih terbuka pada tingkat regional, dan penyesuaian terhadap praktik terbaik (best practices) di tingkat internasional untuk penyelenggaraan, pengaturan, dan pengawasan industri perasuransian.

Mempelajari hukum kenotariatan dan hukum asuransi/pertanggungan di negara lain sebagai suatu alternatif untuk menemukan solusi atau memecahkan permasalahan yang sedang dihadapi bukanlah suatu hal yang salah, asalkan dibatasi hanya sebagai studi perbandingan saja. Menggunakan bahan-bahan banding yang luas, maka dapat memperoleh pengetahuan dan pandangan-pandangan tentang bagaimana negara-negara yang telah maju mengatur hukum asuransi/ pertanggungan yang digunakan oleh para Notaris dalam menjalankan jabatannya.

\section{Penggunaan Asuransi/Pertanggungan di Belanda}

Belanda sebagai negara maju yang menganut system Notarial Civil Law tidak mengatur mengenai cara mengurangi risiko yang ada pada Notaris dalam men- jalankan jabatannya. Tidak ada mengatur mengenai diperbolehkannya atau tidaknya penggunaan asuransi/pertanggungan profesi untuk Notaris di Belanda dalam menjalankan jabatannya, Akan tetapi beberapa perusahaan asuransi/ pertanggungan internasional yang berlisensi memuat negara Belanda sebagai salah satu negara yang dapat mengajukan asuransi/pertanggungan dalam produk Notary Insurance yang mereka tawarkan.

Adanya perusahaan asuransi/ pertanggungan internasional yang berlisensi ke beberapa negara maju yang menawarkan produk Notary Insurance untuk para Notaris dalam menjalankan jabatan atau profesi nya menjadi salah satu cara mengurangi risiko Notaris dalam menjalankan jabatannya. Dengan keadaan yang demikian memang tidak ada aturan penggunaan asuransi/pertanggungan Notaris tapi para Notaris dalam hal ini dapat menggunakan asuransi/ pertanggungan Notaris yang produknya telah disediakan oleh perusahaan asuransi/pertanggungan yang telah menyediakan produk asuransi/ pertanggungan Notaris. ${ }^{15}$

\section{Penggunaan Asuransi/ Pertanggungan di Perancis}

Notaris di Perancis menurut aturan di Perancis diwajibkan ikut asuransi/pertanggungan Notaris dalam menjalankan jabatannya. Hal ini karena ingin menjaga hak klien dan menjaga Notaris dari kerugian yang dideritanya. Bersifat wajib maka asuransi// pertanggungan Notaris di Perancis dikelola oleh Organisasi Profesi

\footnotetext{
15 "Notaris di Belanda," Intercompany Solutions, accessed May 26, 2019, https://id.intercompanysolutions.com/ notaris-di-the-netherlands/
} 
Notaris Perancis. ${ }^{16}$ Aturan klaim asuransi/ pertanggungan Notaris diatur dengan jelas di Perancis, dijelaskan kelalaian dan kerugian yang seperti apa yang dapat digantikan dengan asuransi/ pertanggungan Notaris. Banyak keuntungan yang didapat dengan diwajibkan penggunaan asuransi/ pertanggungan Notaris di Perancis karena membuat para pihak yang menggunakan jasa Notaris lebih aman dan Notaris pun merasa aman tidak khawatir akan risiko apabila terjadi kelalaian dan kesalahan yang disebabkan Notaris. ${ }^{17}$

\section{Penggunaan Asuransi/Pertanggungan di Louisiana}

Notaris di Louisiana diharuskan juga membeli Surety Bond sebagai salah satu cara melindungi Notaris dari risiko-risiko kerugian. Dengan membeli Surety Bond apabila terjadi kelalaian dan kesalahan yang dilakukan Notaris maka akan di klaim menggunakan Surety Bond yang telah mereka beli sebelumnya. Bahkan untuk klaim palsu yang dilakukan klien untuk Notaris juga dapat diganti dengan Surety Bond yang telah dibeli oleh Notaris. ${ }^{18}$

\section{Penggunaan Asuransi/Pertanggungan di Amerika Serikat}

Amerika Serikat adalah negara dengan sistem hukum Common Law. Notaris di Amerika Serikat menggunakan system Notarial Common Law yang kewenangan

\footnotetext{
16 "The role of the French notaire," Notaires de France. Last modified 2017, accessed July 9, 2019, https:// www.notaires.fr/en/notaire/role-notaire-and-hisprincipal-activities/role-notaire.

17 Ibid.

18 "Louisiana Notary Bonds \& Insurance," National Notary Association, accessed May 27, 2019, https:// www.nationalnotary.org/louisiana/insurance.
}

Notarisnya berbeda dengan negara yang memiliki system Notarial Civil Law, untuk Notaris dengan system Notarial Common Law memiliki keterbatasan kewenangan. System Notarial Common Law hanya memverifikasi tanda tangan atau keaslian sebuah dokumen.

Perusahaan asuransi/pertanggungan Notaris di Amerika Serikat juga mengharuskan Notaris membelikan Surety Bond sebagai salah satu cara melindungi Notaris dari risiko yang akan dialami oleh Notaris dalam menjalankan jabatannya. Kewenangan dari system Notarial Common Law yang terbatas tidak seluas kewenangan Notaris system Notarial Civil Law, akan tetapi tetap menggunakan asuransi/pertanggungan untuk mengurangi risiko yang akan dialami.

\section{Kasus Pelaksanaan Klaim Asuransi/Per-} tanggungan di National Notary Association (NNA)

Berikut beberapa kasus tentang klaim Notary Insurance, yaitu:

\section{Kasus penggugat yang keras kepala}

Dalam kasus ini, seorang Notaris diminta untuk mengunjungi rumah sakit dan mengesahkan surat kuasa. Dokumen itu berisi tentang kuasa yang diberikan yang bersangkutan kepada temannya untuk memiliki hak menangani urusan medis dan hukumnya saat pemberi kuasa dirawat dirumah sakit. Kemudian pemberi kuasa mengajukan gugatan terhadap Notaris, mengklaim bahwa si pemberi kuasa tidak mengetahui apa yang ditandatanganinya. ${ }^{19}$

Selama kasus tersebut, penggugat

\footnotetext{
19 "Mission and History," National Notary Association, accessed June, 27, 2019, https:/www.nationalnotary. org/about-the-nna/mission-and-history.
} 
dinyatakan sebagai "penggugat yang menjengkelkan" oleh pengadilan setelah diketahui bahwa ia memiliki riwayat mengajukan tuntutan hukum yang sembrono. Pengacara Notaris mengklaim alasan gugatan itu tidak memadai secara hukum dan pengadilan menguatkan klaim ini. ${ }^{20}$

Tapi, penggugat tidak berhenti. Penggugat mengajukan gugatan kedua terhadap Notaris dan beberapa terdakwa lainnya setahun kemudian. Akhirnya kasus kedua diselesaikan, tetapi tidak sampai Notaris mengeluarkan biaya pengacara tambahan dalam menanggapi tuduhan baru. ${ }^{21}$

Kasus ini mengajarkan pelajaran penting. Litigasi bisa menjadi berantakan, dan kadang-kadang orang yang dapat berperkara tidak menyerah. Akibatnya, Notaris dapat dikenakan biaya yang signifikan dalam membela diri bahkan terhadap klaim sembrono. Dalam hal ini, Notaris memiliki kesalahan dan kelalaian polis asuransi/pertanggungan dan butuh sejumlah polis yang besar untuk mempertahankan Notaris dalam kedua proses litigasi tersebut. $^{22}$

\section{Kasus Notaris tertangkap dalam pertika- ian}

Dalam kasus ini, Notaris berada di antara beberapa orang yang dituntut lebih dari \$ 200.000 atas transaksi real estate. Penggugat mengklaim Notaris telah gagal untuk memeriksa dengan benar identitas penandatangan selama transaksi. Investigasi kemudian membebaskan Notaris dari semua kesalahan. Namun, gugatan tersebut sangat sulit dan mahal untuk diselesaikan

${ }^{20}$ Ibid.
${ }^{21}$ Ibid.
${ }^{22}$ Ibid.

karena banyak pengaduan-pengaduan dan pengaduan melibatkan banyak terdakwa. ${ }^{23}$

Risiko keuangan sebagai Notaris sering sekali menjadi taruhan atas kasus seperti ini. Notaris bisa saja benar tapi masih berakhir dengan tagihan hukum. Untungnya, adanya asuransi/pertanggungan Notaris dalam hal ini membayar biaya hukum. ${ }^{24}$

\section{Kasus Thumbprint yang mahal}

Dalam hal ini, kekeliruan saat merekam entri jurnal membuat Notaris mengalami masalah hukum serius. Selama Notaris yang melibatkan property nyata, Notaris terganggu dan gagal untuk mengambil cap jempol tangan dari penandatangan jumlahnya seperti dipersyaratkan oleh hukum negara. Belakangan diketahui bahwa penandatangan itu adalah penipu, dan Notaris digugat $\$ 250.000 .^{25}$

Setelah negosiasi panjang, kasus ini akhirnya diselesaikan. Tetapi hasil negosiasi tersebut membuat klaim asuransi/ pertanggungan Notaris menjadi habis. Pelajaran yang didapat disini bahwa asuransi/ pertanggungan akan mencakup klaim hingga batas kebijakan mereka ketika Notaris lalai, seperti dalam kasus ini dimana Notaris lupa untuk mendapatkan cap jempol tangan dari penanda di entri jurnal. ${ }^{26}$

\section{Kasus beberapa kesalahan}

Dalam kasus ini, Notaris diminta untuk mengesahkan tanda tangan dua orang yang menandatangani akta kepercayaan untuk membeli properti. Karena para penandatangan tidak memiliki ID (identitas diri),

\footnotetext{
${ }^{23}$ Ibid.

${ }^{24}$ Ibid.

${ }^{25}$ Ibid.

${ }^{26}$ Ibid.
} 
Notaris mengidentifikasi mereka dengan menggunakan saksi pengindentifikasi yang kerdibel, yaitu agen yang mewakili para penandatangan. Hukum negara mengharuskan Notaris untuk mengenal saksi secara pribadi, tetapi Notaris hampir tidak mengenal agennya. Selain itu, Notaris gagal mendapatkan cap jempol dari penandatanganan di jurnalnya. Biaya penyelesaian dan hukum sangat besar. Notaris yang akan dituntut setelah mengikuti prosedur yang tepat, bisa saja situasinya menjadi lebih buruk jika Notaris mengabaikan aturan negara ketika memverifikasi identitas penandatangan. ${ }^{27}$

Dengan mengabaikan aturan untuk Notaris yang mengidentifikasi penandatangan dan memperoleh cap jempol, terdakwa dalam kasus ini tidak hanya menghadapi tuntutan hukum yang mahal tetapi membuat transaksi rentan terhadap potensi penipuan. Bahkan seorang ahli tulisan tangan menunjukkan bahwa itu "sangat mungkin" tanda tangan yang diaktakan berdasarkan akta kepercayaan yang dipertanyakan telah dipalsukan. Untungnya bagi Notaris yang telah memiliki asuransi/ pertanggungan Notaris, Notary Insurance berlaku untuk klaim tersebut selama pelanggaran tidak sengaja. ${ }^{28}$

\section{Penerapan Asuransi/Pertanggungan bagi Notaris dalam Menjalankan Jabatan}

Notaris adalah pejabat umum yang diangkat oleh pejabat yang berwenang jelas berbeda dengan profesi. Notaris sebagai pejabat umum memiliki kewenangan yang diberikan oleh negara melalui Undang-Undang Jabatan Notaris. Notaris sebagai pejabat umum me-

\footnotetext{
${ }^{27}$ Ibid.

${ }^{28}$ Ibid.
}

merlukan perlindungan hukum yang maksimal dari negara sebagai salah satu hak dari Notaris karena jabatan yang diberikan kepada Notaris. Menurut Philipus M. Hadjon berpendapat bahwa perlindungan hukum adalah perlindungan akan harkat dan martabat, serta pengakuan terhadap hak-hak asasi manusia yang dimiliki oleh subjek hukum berdasarkan ketentuan hukum kesewenangan. ${ }^{29}$ Menurut CST Kansil perlindungan hukum adalah berbagai upaya hukum yang harus diberikan oleh aparat penegak hukum untuk memberikan rasa aman, baik secara pikiran maupun fisik dari gangguan dan berbagai ancaman dari pihak manapun. ${ }^{30}$

Membahas tentang perlindungan hukum maka perlindungan hukum bagi Notaris dalam menjalankan jabatannya harus dipenuhi oleh negara disamping perlindungan hukum terhadap Notaris sebagai warga negara biasa. Notaris memiliki dua sisi dimata hukum, sisi pertama Notaris sebagai pejabat umum yang berwenang dan sisi kedua Notaris sebagai individu sebagai warga negara.

Perlindungan hukum bagi Notaris berupa asuransi/pertanggungan Jabatan Notaris perlu adanya peran pemerintah dan peran organisasi dalam hal ini Ikatan Notaris Indonesia (INI) sebagai penyambung atas gagasan baik tentang adanya asuransi/perlindungan Notaris dalam menjalankan jabatan. Perlunya ada aturan yang dibuat sebagai dasar lahirnya asuransi/pertanggungan jabatan Notaris agar Notaris dalam menjalankan jabatannya dapat mengurangi risiko yang akan terjadi nanti dikemudian hari.

\footnotetext{
29 "Pengertian Perlindungan Hukum Menurut Ahli," Tesis Hukum, last modified 2014, accessed July 10, 2019, http://tesishukum.com/pengertianperlindungan-hukum-menurut-para-ahli/.

${ }^{30}$ Ibid.
} 
Notaris dalam menjalankan jabatannya sebagai pejabat umum yang memiliki perpanjangan dari kewenangan pemerintah yang membantu berbagai tugas, terutama bidang keperdataan maka seorang Notaris harusnya dilindungi oleh Negara secara maksimal dalam menjalankan jabatannya. Sesuai dengan cita-cita hukum kenotariatan yang salah satunya adalah terciptanya kepastian hukum, ketertiban masyarakat, dan terpenuhinya perlindungan hukum dan berkaitan dengan arah kebijakan hukum kenotariatan, maka perlindungan hukum terhadap Notaris dalam menjalankan jabatannya harusnya dimuat dalam Undang-Undang Peraturan Jabatan Notaris secara jelas. Selama ini hal mengenai perlindungan hukum terhadap Notaris dalam menjalankan jabatannya belum dimuat dalam Undang-Undang Peraturan Jabatan Notaris.

Asuransi/pertanggungan untuk jabatan Notaris seperti yang telah dijelaskan diatas sebelumnya yaitu mengenai asuransi/pertanggungan untuk profesi. Asuransi/pertanggungan untuk jabatan Notaris merupakan asuransi/pertanggungan umum yang merupakan asuransi/pertanggungan kerugian yang merupakan bagian produk baru dari perusahaan asuransi/pertanggungan karena kebutuhan yang ada dikalangan Notaris. Asuransi/pertanggungan ini bersifat sukarela.

Menurut Yedi Dwinugro Kepala Seksi Asuransi Umum PT Bumiputera Muda 1967 (Bumida) cabang Banjarmasin mengatakan bahwa Asuransi Umum PT Bumiputera Muda 1967 (Bumida) telah mengeluarkan produk asuransi/ pertanggungan tanggung gugat jabatan Notaris yang telah dikeluarkan pada awal tahun 2019. Tapi karena masih tergolong produk baru belum dipasarkan secara luas, khususnya untuk daerah Banjarmasin produk asuransi/pertanggungan tanggung gugat No- taris ini belum dipasarkan atau ditawarkan kepada para Notaris karena masih perlu waktu mempelajari produk baru yaitu asuransi/ pertanggungan tanggung gugat Notaris ini sebelum dipasarkan atau ditawarkan. ${ }^{31}$

Manfaat yang akan didapat oleh Notaris apabila menggunakan produk Asuransi Tanggung Gugat Notaris yang dimiliki oleh Asuransi Umum PT Bumiputera Muda 1967 (Bumida), yaitu: ${ }^{32}$

a. Tanggung gugat perdata;

b. Tanggung gugat atas pelanggaran hak atas kekayaan intelektual;

c. Tanggung gugat atas pencemaran nama baik;

d. Tanggung gugat atas pelanggaran perlindungan data;

e. Tanggung gugat terkait internet;

f. Tanggung gugat atas kelalaian karyawan Notaris;

g. Biaya pembelaan hukum.

Manfaat dari asuransi tanggung gugat Notaris diperluas dengan: ${ }^{33}$

1. Penanggung akan memberikan ganti rugi atas kerusakan atau kehilangan atau perubahan bentuk kelalaian dalam peletakan dokumen milik pihak ketiga dalam ruang lingkup pekerjaan kenotariatan; dan

2. Dengan dasar pengajuan tertulis dari tertanggung dan ditindaklanjuti dengan persetujuan tertulis dari penanggung untuk membayarkan uang muka biaya pembelaan hukum kepada tertanggung sebelum keputusan final atas gugatan hukum pihak ketiga.

${ }^{31}$ Wawancara dengan Kepala Seksi Asuransi Umum PT Bumiputera Muda 1967 (Bumida) cabang Banjarmasin, pada tanggal 11 Juli 2019.

${ }^{32}$ Asuransi Umum PT Bumiputera Muda 1967 (Bumida). 2019. Brosur Produk Asuransi Tanggung Gugat Notaris.

${ }^{33}$ Ibid. 
Membahas tentang pentingnya perlindungan hukum bagi Notaris terhadap risiko dalam pelaksanaan jabatan Notaris selain menggunakan asuransi/pertanggungan jabatan Notaris yang disediakan oleh perusahaan asuransi dapat juga dilakukan perlindungan hukum yang sistemnya melalui organisasi Ikatan Notaris Indonesia sebagai organisasi Notaris di Indonesia yang dengan sistem menarik iuran dari para anggota dan kemudiaan mengelolanya sehingga apabila ada seorang Notaris dalam melaksanakan jabatannya telah melakukan kesalah atau kelalaian yang menyebabkan kerugian maka akan diberikan bantuan berdasarkan uang iuran para anggota Ikatan Notaris Indonesia sebagai salah satu wujud perlindungan hukum yang diberikan melalui organisasi Ikatan Notaris Indonesia.

Perlindungan dalam bentuk asuransi/ pertanggungan jabatan Notaris dalam pelaksanaan jabatan Notaris dirasa salah satu cara yang lebih efektif untuk memberikan perlindungan hukum bagi Notaris dalam melaksanakan jabatan Notaris. Dalam masalah pengelolaan dana untuk perlindungan atas risiko yang menimbulkan kerugian bagi Notaris dalam menjalankan jabatan maka menurut penulis perusahaan asuransi/pertanggungan lebih berpengalaman dalam mengelola dana yang dikumpulkan sebagai salah satu cara untuk pengalihan risiko oleh klien kepada perusahaan asuransi/ pertanggungan.

\section{Penggunaan Asuransi/Pertanggungan ter- hadap Risiko dalam Pelaksanaan Jabatan Notaris}

\section{Risiko yang Menjadi Dasar Pembukaan Asuransi/Pertanggungan Dalam Men- jalankan Jabatan Notaris}

Risiko mempunyai unsur ketidakpastian (uncertainty) dan tidak bisa diramal- kan secara pasti pada hari ini. Ketidakpastian tersebut menyebabkan kemungkinan adanya ketidaksesuaian antara pencapaian hasil dengan tujuan yang diharapkan. Terkait dengan hal tersebut, perusahaan harus selalu berusaha untuk mengatasinya dengan berbagai cara. Pengelolaan berbagai cara penanggulangan risiko inilah yang seribut disebut manajemen risiko. ${ }^{34}$

Fenomena yang dialami dalam pelaksanaan jabatan Notaris, yaitu:

a. Tidak seimbangnya antara pendapatan dan pengeluaran Notaris;

b. Persaingan tidak sehat antar Notaris;

c. Adanya Notaris yang tidak aktif; dan

d. Adanya tuntutan bagi Notaris sehingga Notaris memerlukan biaya untuk berperkara di pengadilan.

Apabila akta yang telah dibuat oleh Notaris melanggar peraturan perundangundangan dan kekuatan pembuktiannya sebagai akta dibawah tangan atau suatu akta menjadi batal demi hukum, maka dapat menjadi alasan bagi pihak yang menderita kerugian untuk menuntut Notaris penggantian biaya, ganti rugi, dan bunga. ${ }^{35}$

\section{Konstruksi Asuransi/Pertanggungan} Atas Risiko Pelaksanaan Jabatan Notaris

Perlindungan hukum atas jabatannya yang diberikan kepada Notaris harus diberikan negara karena Notaris adalah pejabat umum yang diangkat oleh pejabat yang berwenang. Notaris dalam menjalankan jabatannya memiliki risiko-risiko yang mengiringi kewenangannya, yang dalam penelitian ini peneliti membahas mengenai risiko Notaris yang apabila dalam men-

\footnotetext{
${ }^{34}$ Mulhadi, Dasar-Dasar Hukum Asuransi, Cetakan 1. (Depok: PT.RajaGrafindo Persada, 2017), 28.

${ }^{35}$ Ibid., 242.
} 
jalankan jabatannya melakukan kesalahan atau kelalaian sehingga adanya tuntutan di pengadilan dan menyebabkan adanya tuntutan ganti rugi yang besarannya tidak pasti dapat diperkirakan besarannya. Perlindungan hukum atas hal tersebut diperlukan bagi Notaris, salah satunya dengan melakukan pengalihan risiko ke perusahaan asuransi/pertanggungan.

Melihat dari kriteria asuransi/pertanggungan kerugian maka risiko Notaris dalam menjalankan jabatannya masuk kedalam kriteria asuransi/pertanggungan kerugian. Tapi lebih jelasnya masuk asuransi/ pertanggungan kerugian dalam bentuk professional insurance atau asuransi/ pertanggungan profesi. Dijelaskan sebelumnya bahwa Notaris adalah jabatan bukan profesi maka bentuknya akan lebih baik dengan sebutan Notary Insurance atau asuransi/pertanggungan Notaris.

\section{PENUTUP}

\section{Kesimpulan}

1. Urgensi penggunaan asuransi/ pertanggungan jabatan Notaris merupakan hal yang penting mengingat risiko-risiko yang mengikuti Notaris dalam pelaksanaan jabatannya. Penggunaan asuransi/ pertanggungan jabatan Notaris merupakan suatu bentuk perlindungan hukum yang diberikan kepada Notaris sebagai pejabat umum yang diangkat oleh pejabat yang berwenang. Urgensi penggunaan asuransi/pertanggungan jabatan Notaris agar seorang Notaris dalam menjalankan jabatannya merasa aman karena memiliki perlindungan akan risiko-risiko yang akan dihadapinya dalam pelaksanaan jabatan Notaris.

2. Berdasarkan risiko yang ada dalam pelak- sanaan jabatan Notaris maka peneliti mengkonstruksi bentuk asuransi/pertanggungan Notaris dalam menjalankan jabatannya. Pengalihan risiko diberikan kepada perusahaan asuransi/pertanggungan dalam bentuk asuransi/ pertanggungan kerugian yang lebih spesifik menjadi Professional Insurance dan lebih jelas lagi yaitu Notary Insurance. Notary Insurance memberikan perlindungan terhadap risiko-risiko yang dihadapi oleh Notaris dalam pelaksanaan jabatan Notaris yang berkaitan dengan kenotariatan, bukan untuk melindungi Notaris berdasarkan kedudukan Notaris sebagai individu.

\section{Saran}

1. Perlunya perlindungan hukum yang maksimal diberikan kepada Notaris dalam menjalankan jabatan Notaris terkait risiko-risiko yang akan dihadapi Notaris. Untuk memberikan perlindungan hukum yang maksimal maka perlunya ada dukungan dari pemerintah dalam hal ini pembuat undang-undang untuk memuat aturan dalam Undang-Undang Peraturan Jabatan Notaris dengan menambahkan isi dari Undang-Undang Peraturan Jabatan Notaris tentang perlindungan hukum yang diberikan kepada Notaris.

2. Perlunya ada aturan jelas mengenai penggunaan asuransi/pertanggungan profesi di Indonesia. Untuk penggunaan dan bentuk dari asuransi/pertanggungan jabatan Notaris juga perlu diatur dalam UndangUndang Peraturan Jabatan Notaris karena Notaris merupakan pejabat umum yang dalam menjalankan jabatannya berdasarkan Undang-Undang Peraturan Jabatan Notaris. 


\section{BIBLIOGRAFI}

\section{Buku}

Anshori, Abdul Ghofur. Lembaga Kenotariatan Indonesia Perspektif Hukum dan Etika. Cetakan IV. Yogyakarta: UII Press Yogyakarta, 2016.

Budiman, Andre Panjaitan, and Angger Sigit Pramukti. Pokok-Pokok Hukum Asuransi. Cetakan I. Yogyakarta: Pustaka Yustia, 2016.

Mamudji, Sri and Soerjono Soekanto. Penelitian Hukum Normatif Suatu Tinjauan Singkat. Cetakan XVIII. Jakarta: PT. RajaGrafindo Persada, 2018.

Marzuki, Peter Mahmud. Penelitian Hukum Edisi Revisi. Jakarta: PT.Kharisma Putra Utama, 2005.

Mulhadi. Dasar-Dasar Hukum Asuransi. Cetakan I. Depok: PT.Raja Grafindo Persada, 2017.

Prodjodikoro, Wirjono. Hukum Asuransi di Indonesia. Jakarta: PT.Intermasa, 2007.

Sjaifurrahman. Aspek Pertanggungjawaban Notaris dalam Pembuatan Akta. Mandar Maju,Bandung, 2011.

\section{Jurnal}

Enggarwati, Irene Dwi, Suhariningsih, and Muchammad Ali Syafa'at. "Pertanggungjawaban Pidana dan Perlindungan Hukum Bagi Notaris yang Diperiksa oleh Penyidik Dalam Tindak Pidana Keterangan Palsu Pada Akta Otentik" Kumpulan Jurnal Mahasiswa Fakultas Hukum Universitas Brawijaya 5, no. 1 (2015): 9. http:// hukum.studentjournal.ub.ac.id/index. php/hukum/article/view/1394

Pratama, Aji Surya, Abdul Halim Barkatullah, and Rahmida Erliyani. "Kedudukan Dana Asuransi Jiwa Dalam Relevansinya Dengan Pembagian Harta Warisan." Lambung Mangkurat Law Journal 4, no 1
(2019): 18. https://lamlaj.ulm.ac.id/web/ index.php/abc/article/view/93

\section{Internet}

Elnizar, Norman Edwin. “ Waspadai Tuntutan Pidana yang Mungkin Dihadapi Notaris dalam Bertugas"Hukum Online. Last modified 2018. Accessed August, 19 2020. https:/www.hukumonline.com/ berita/baca/1t5a7ae033bc871/waspadaituntutan-pidana-yang-mungkin-dihadapi-notaris-dalam-bertugas/.

"Notaris di Belanda" Intercompany Solutions. Accessed May, 2019. https:// id.intercompanysolutions.com/notarisdi-the-netherlands/ .

"Mission and History" National Notary Association. Accessed June 27, 2019. https:// www.nationalnotary.org/about-the-nna/ mission-and-history.

"Louisiana Notary Bonds \& Insurance" $\mathrm{Na}$ tional Notary Association. Accessed May 27, 2019. https://www.nationalnotary. org/louisiana/insurance.

"The role of the French notaire" Notaires de France. Last modified 2017. Accessed July 9, 2019. https://www.notaires.fr/en/ notaire/role-notaire-and-his-principal-activities/role-notaire.

"Pengertian Perlindungan Hukum Menurut Ahli” Tesis Hukum. Last modified 2014. Accessed July 10, 2019. http://tesishukum.com/pengertian-perlindungan-hukum-menurut-para-ahli/.

\section{Wawancara}

Wawancara dengan Kepala Seksi Asuransi Umum PT Bumiputera Muda 1967 (Bumida) cabang Banjarmasin, pada tanggal 11 Juli 2019.

\section{Pamflet}

Asuransi Umum PT Bumiputera Muda 1967 (Bumida). 2019. Brosur Produk Asuransi 
Tanggung Gugat Notaris.

Peraturan Perundang-Undangan

Kitab Undang-Undang Hukum Perdata (Burgerlijk Wetboek), (Staatblaad Nomor 23 Tahun 1847 tentang Burgerlijk Wetboek Voor Indonesie).

Kitab Undang-Undang Hukum Dagang (Wetboek Van Koophandel), (Staatblaad Nomor 23 Tahun 1847 tentang Wetboek Van Koophandel Voor Indonesie).

Peraturan Pemerintah Nomor 14 Tahun 2018 Tentang Kepemilikan Asing Pada Perusahaan Perasuransian (Lembaran Negara Republik Indonesia Tahun 2018 Nomor 66, Tambahan Lembaran Negara Republik Indonesia Nomor 6200).

Undang-Undang Dasar Republik Indonesia 1945.
Undang-Undang Nomor 2 Tahun 2014 Tentang Jabatan Notaris (Lembaran Negara Republik Indonesia Tahun 2014 Nomor 3, Tambahan Lembaran Negara Republik Indonesia Nomor 5491).

Undang-Undang Nomor 40 Tahun 2014 Tentang Usaha Perasuransian (Lembaran Negara Republik Indonesia Tahun 2014 Nomor 337, Tambahan Lembaran Negara Republik Indonesia Nomor 5618). 